\title{
Pengaruh CEO Power Dan Political Connections Terhadap Pemilihan Auditor Berkualitas
}

\author{
Slamet Wahyudi ${ }^{1}$ Dede Nursaman ${ }^{2} \&$ Syahril Djaddang ${ }^{3}$ \\ ${ }^{123^{2}}$ Sekolah Tinggi Ilmu Ekonomi Hidayatullah, Depok, Indonesia \\ Email : dede.nursaman@stiehidayatullah.ac.id
}

\begin{abstract}
Financial statements must be presented fairly and can be trusted. Improving the quality of financial statements can be done by appointing the services of an independent auditor. This study aims to analyze and find empirical evidence of the effect of CEO power and political connections on the selection of quality auditors. The sample in this study consisted of 45 annual reports of LQ45 index companies listed on the Indonesia Stock Exchange for the 2018 period. The analysis technique used logistic regression. The results showed that CEOs who have stronger power than share ownership in the companies they lead tend to choose quality auditors. However, political connections through share ownership by the government have no effect in selecting quality auditors in LQ45 index companies listed on the Indonesia Stock Exchange.
\end{abstract}

Keywords: auditor selection, CEO power, political connections

\begin{abstract}
ABSTRAK
Laporan keuangan harus disajikan secara wajar dan dapat dipercaya. Peningkatkan kualitas laporan keuangan dapat dilakukan dengan cara penunjukan jasa auditor independen. Penelitian ini bertujuan untuk menganalisis dan menemukan bukti empiris pengaruh CEO power dan poitical connections terhadap pemilihan auditor berkualitas. Sampel dalam penelitian ini terdiri dari 45 laporan tahunan perusahaan indeks LQ45 yang terdaftar di Bursa Efek Indonesia periode 2018. Teknik analisis menggunakan regresi logistik. Hasil penelitian meunjukan CEO yang memiliki power lebih kuat dari kepemilikan saham pada perusahaan yang dipimpinnya cendrung memilih auditor berkualitas. Namun political connections melalui kepemilikan saham oleh pemerintah tidak berpengaruh dalam memilih auditor berkualitas di perusahaan index LQ45 yang terdaftar di Bursa Efek Indonesia.
\end{abstract}

Kata Kunci : pemilihan auditor, CEO power, political connections

\section{PENDAHULUAN}

(Kartikahadi, Sinaga, Syamsul, \& Siregar, 2012) mengatakan tujuan dari penyajian laporan keuangan yaitu menyediakan informasi yang berkaitan posisi keuangan, kinerja, serta perubahan posisi keuangan suatu perusahaan yang bermanfaat untuk para pemilik kepentingan dalam mengambil keputusan ekonomi. Adanya kebutuhan atas informasi keuangan yang berkualitas mengakibatkan pentingnya perusahaan menggunakan jasa auditor independen sebagai perantara kepentingan pemilik dengan manajemen (Arens et al., 2015). Auditor independen melakukan fungsi pengawasan dan menguji informasi akuntansi yang dibuat oleh manajemen sehingga informasi yang sampai kepeda para pemilik kepentingan adalah informasi yang dapat dipercaya dan diandalkan.

Berkaitan dengan audit yang diyakini dapat meningkatkan kualitas laporan keuangan. (DeAngelo, 1982) mengatakan audit merupakan faktor yang sulit diukur kualitasnya secara langsung, adapun proksi yang bisa digunakan untuk mengukur kualitas audit yaitu ukuran dari kantor akuntan publik, dimana semakin besar ukuran kantor akuntan publik,
Submitted: MARET 2021

Accepted: APRIL 2021

\section{JIAKES}

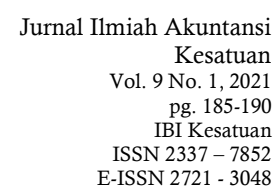
Kesatuan Vol. 9 No. 1, 202 pg. $185-190$ IBI Kesatuan ISSN $2337-7852$ E-ISSN 2721 - 3048 
Auditor, $C E O \quad$ maka kantor akuntan publik tersebut akan memberikan layanan audit dengan kualitas Power and Political lebih tinggi. (Balsam et al., 2005) mengatakan kualitas audit dapat diproksikan dengan Connection brand auditor. Brand auditor yang hingga kini dikenal adalah big 4 yang menjadi acuan kualitas audit karena auditor yang memiliki afiliasi dengan auditor big 4 dipercaya memiliki standar yang tinggi dalam menerapkan proses audit sehingga menghasilkan audit yang berkualias.

Tabel 1 Pemilihan auditor perusahaan jasa non keuangan yang terdafatar di BEI

\begin{tabular}{ccccc} 
& Tahun & Non Big $\mathbf{4}$ & Big $\mathbf{4}$ & Grand Total \\
\cline { 2 - 5 } & 2015 & 41 & 19 & 60 \\
\cline { 2 - 5 } & 2016 & 39 & 21 & 60 \\
\hline 2017 & 39 & 21 & 60 \\
\cline { 2 - 5 } & 2018 & 40 & 20 & 60 \\
\hline
\end{tabular}

Berdasarkan data diatas menunjukan pada perusahaan jasa non keuangan yang terdafatar di BEI periode 2015-2018 lebih banyak perusahaan yang menggunakan jasa auditor non big 4 yaitu 159 dibandingkan perusahaan yang menggunakan jasa auditor big 4 yaitu 81. Hal ini menjadi sebuah fenomena dimana perusahaan yang terdaftar di BEI dengan kepemilikan saham yang dimiliki masyarakat umum dan diharapkan menyajikan laporan keuangan yang telah dipersiapkan dengan baik dan diaudit secara transparan oleh auditor berkualitas dalam hal ini big 4 masih lebih banyak memilih auditor non big 4 .

Adanya fenomena pemilihan auditor non big 4 oleh perusahaan jasa non keuangan yang terdaftar di BEI ini menjadi hal yang menarik untuk dilakukan analsia lebih lanjut mengenai faktor-faktor yang dapat mempengaruhi suatu perusahaan dalam memutuskan untuk memilih auditor big 4 atau non big 4 sebagai upaya perusahaan dalam meningkatkan kualitas informasi laporan keuangan yang menjadi dasar pengambilan keputusan bagi para pemegang kepentingan.

Beberapa penelitian mengenai faktor-faktor yang mempengaruhi pemilihan auditor diantaranya (Ouyang et al., 2015) mengungkapkan bagaimana peranan $C E O$ dalam pemilihan auditor. Hasilnya $C E O$ yang memiliki power lebih kuat cendrung memilih auditor berkualitas sebagai sinyal untuk memberikan laporan keuangan yang sangat berkualitas. Dilain pihak penelitian mengani $C E O$ power yang dilakukan di Indonesia oleh (Palembangan \& Dewi, 2017) mengatakan dengan adanya kekuasaan $C E O$ yang tinggi, perusahaan cendrung memilih auditor non big 4 .

Berikutnya (Guedhami et al., 2014) mengidenfikasi perusahaan publik yang memiliki political connections lebih memilih audior big 4 demi menunjukan bahwa orang dalam perusahaan ingin meningkatkan transparansi akuntansi untuk meyakinkan investor dari luar bahwa mereka menahan diri dari memanfaatkan koneksi untuk menguasai sumber daya perusahaan. Sementara (Habib et al., 2017) mengatakan transaksi dengan pihak yang berelasi sebagai faktor pendorong perusahaan yang memiliki koneksi politis untuk memilih auditor non big 4 .

Adapun tujuan penelitian ini untuk menganalisis bagaimana pengaruh $C E O$ power dan political connections terhadap pemilihan auditor berkualitas pada perusahaan yang terdaftar di Bursa Efek Indonesia.

(Jensen \& Meckling, 1976) mengatakan bahwa hubungan keagenan adalah sebuah kontrak dimana satu orang atau lebih pemilik (investor) melibatkan orang lain (agen) untuk melakukan beberapa hal atas nama pemilik (investor) dengan mendelegasikan wewenang pengambilan keputusan kepada mereka. Hubungan tersebut ditujukan untuk memaksimalkan keuntungan (kepentingan pemilik) sementara agen cendrung memanfaatkan sumber daya perusahaan untuk kepentingannya sendiri. Hal tersebut mengakibatkan terjadinya konflik kepentingan antara agent dan principal. 
Dalam bukunya (Arens et al., 2015) mengatakan auditing adalah pengumpulan dan evaluasi bukti-bukti informasi untuk menentukan dan melaporkan tingkat kesesuaian antara informasi dengan kriteria yang ditetapkan. Auditing harus dilakuan oleh orang yang kompeten dan independen. CEO di Indonesia perannya lebih dikenal dengan direktur utama yakni orang yang memimpin dan bertanggung jawab menentukan strategi dan visi perusahaan untuk menjaga keberlangsungan perusahaan serta dapat berkembang menjadi lebih baik lagi. Atas tanggung jawabnya tersebut $C E O$ memiliki pengaruh yang cukup besar dalam pengambilan keputusan yang berdampak bagi kelangsungan perusahaan ke depan termasuk dalam pemilihan auditor.

Merujuk dari literatur (Finkelstein, 1992) mendefinisikan power dari dimensi keuangan perusahaan adalah kapasitas seseorang untuk mengerahkan kehendaknya dimana kapastias itu terdiri dari empat sumber kekuasaan yaitu kekuasaan strukural, kekuasaan kepemilikan, kekuasaan keahlian, dan kekuasaan kehormatan. CEO power dapat didefiniskan sebagai sejauh mana kapasitas $C E O$ dalam mengerahkan kehendaknya untuk memimpin perusahaan sehingga dapat mencapai tujuan sesuai apa yang dikehendaki. (Faccio, 2006) menyebutkan political connection firms dapat dilihat sebagai suatu kondisi dimana suatu perusahaan setidaknya salah satu dari top officer, pemegang saham besar atau kerabat mereka adalah pemegang jabatan politik tinggi atau seorang politikus yang ternama. (Anugerah Endriawan Sudarno, 2015; Prayugi, 2015) mengatakan perusahaan dengan kepemilikan oleh negara (BUMN) tidak lepas dari unsur politik sehingga dianggap memiliki koneksi politik yang dapat mempengaruhi perusahaan dalam mengambil keputusan strategis termasuk pemilihan auditor.

\section{METODE PENELITIAN}

Populasi dalam penelitian ini adalah perusahaan yang terdaftar di Bursa Efek Indonesia periode 2018. Pengambilan sampel dilakukan menggunakan metode purposive sampling yaitu mengambil sampel dari populasi berdasarkan kriteria-kriteria tertentu. Sampel yang digunakan dalam penelitian ini berdasarkan kriteria sebagai berikut :

a. Perusahaan LQ45 yang terdaftar di BEI periode 2018

b. Memiliki data lengkap untuk semua variabel penelitian dalam periode penelitian Model regresi yang digunakan dalam penelitian ini adalah regresi logistik, dikarenakan penguji menggunakan variabel dependen dengan ukuran binnary atau dummy. Varibel dependen yaitu pemilihan auditor yang diproksikan dengan auditor big 4 dan non big 4 . Variabel Independen pertama adalah CEO power yang diproksikan dengan kekuasaan yang dimiliki oleh direktur utama dalam perusahaan. Pengukuran yang dilakukan dengan memberikan angka 1 jika CEO memiliki kekuasaan struktural dan kekuasaan kepemilikan dari suatu perusahaan, kemudian angka 0 jika CEO hanya memiliki kekuasaan struktural atau sama halnya jika direktur utama hanya menjabat sebagai CEO. Variabel independent kedua adalah political connections yang diproksikan dengan perusahaan yang memiliki hubungan politik melalui kepemilikan oleh negara. Pengukuran yang dilakukan dengan memberikan angka 1 jika perusahaan adalah BUMN, kemudian angka 0 jika perusahaan adalah bukan BUMN.

\section{HASIL DAN PEMBAHASAN \\ Deskripsi Objek Penelitian}

Data yang disajikan dalam penelitian ini merupakan data sekunder yang berasal dari perusahaan yang terdaftar di Bursa Efek Indonesia. Objek penelitian yang digunakan dalam penelitian ini adalah laporan tahunan (annual report) perusahaan yang masuk dalam indeks LQ45 periode Juli-Desember 2018 sehingga jumlah sampel sebanyak 45.

Analisa Data

Tabel 2 Hosmer and Lemeshow's Test Goodness of Fit Test

\begin{tabular}{|c|c|c|}
\hline Chi square & Df & Sig. \\
\hline 0,004 & 2 & 0,998 \\
\hline
\end{tabular}

Sumber : data diolah
Auditor, CEO

Power and Political

Connection 
Auditor, CEO

Power and Political

Connection

188

Nilai chi square tabel untuk derajat bebas (df) 2 pada taraf signifikan 0.1 adalah sebesar 4,605. Berdasarkan tabel 2 dapat diketahui nilai chi square hosmer and lemeshow 0,004 dengan signifikan 0,998 dan derajat bebas (df) 2. Dari hasil uji hosmer and lemeshow's test goodness of fit test pada tabel 2 dapat dilihat bahwa nilai chi square kurang dari nilai tabel chi square $(0,004<4,605)$ dan signifikan lebih besar dari alpha $(0,994>0.1)$ yang berarti tidak ada perbedaan antara model dengan data observasi sehingga dapat disimpulkan bahwa model dengan data layak ( $f i t)$ untuk digunakan.

Tabel 3 Variabel in the Equation

\begin{tabular}{|c|c|c|c|c|c|c|}
\hline & B & S.E. & Wald & df & Sig. & Exp (B) \\
\hline CEOPOW & 1,317 & 0,749 & 3,094 & 1 & 0,079 & 3,733 \\
\hline POLCON &,- 0257 & 0,713 & 0,130 & 1 & 0,719 & 0,773 \\
\hline Constant & 0,500 & 0,487 & 1,052 & 1 & 0,305 & \\
\hline
\end{tabular}

Sumber : data diolah

Tabel 3 diatas merupakan tabel yang digunakan untuk menguji hipotesis dimana jika nilai wald lebih besar dari nilai chi square tabel atau nilai signifikansi dibawah alpha yang ditentukan maka variabel tersebut dianggap berpengaruh signfikan. Nilai chi square tabel untuk derajat bebas (df) 1 pada taraf signifikansi 0,1 adalah sebesar 2,705. Taraf signifikansi atau alpha yang digunakan adalah 0,1 hal ini karena sampel yang digunakan hanya 45 dan 1 periode yaitu 2018. Variabel CEO power (CEOPOW) memiliki nilai wald lebih besar dari nilai chi square tabel $(3,094>2,705)$ dengan signifikansi dibawah alpha $(0,079<0,1)$ sehingga dapat dikatakan $C E O$ power memiliki pengaruh yang signifikan terhadap pemilihan auditor berkualitas. Hasil ini sesuai dengan hipotesis yang diajukan yaitu CEO power berpengaruh terhadap pemilihan auditor berkualitas. Variabel political conections (POLCON) memiliki nilai wald lebih kecil dari nilai chi square tabel $(0,130<2,705)$ dengan signifikansi diatas alpha $(0,719>0,1)$ sehingga dapat dikatakan political conections tidak memiliki pengaruh yang signifikan terhadap pemilihan auditor berkualitas. Hasil ini menolak hipotesis yang diajukan yaitu political conections berpengaruh terhadap pemilihan auditor berkualitas.

\section{Pembahasan}

Berdasarkan hasil pengujian yang telah dilakukan, terbukti CEO power (CEOPOW) berpengaruh positif dan signifikan terhadap pemilihan auditor berkualitas pada perusahaan yang masuk kedalam indeks $L Q 45$ di Bursa Efek Indonesia. Hasil ini sesuai dengan hipotesis yang diajukan sehingga dapat diketahui $C E O$ yang mempunyai saham pada perusahaan yang dipimpinnya cendrung untuk menggunakan auditor berkualitas yaitu big 4 pada perusahaan yang masuk kedalam indeks $L Q 45$ di Bursa Efek Indonesia. Hasil ini sejalan dengan penelitian (Ouyang et al., 2015) yang mengatakan $C E O$ yang memiliki power lebih kuat cendrung memilih auditor berkualitas. CEO yang memiliki power lebih kuat dengan kepemilikannya di perusahaan memberikan sinyal kepada para pemegang kepentingan bahwa perusahaan berupaya menyajikan laporan yang sangat berkualitas dengan memilih auditor big 4. Selain itu, perusahaan menjadi sangat diminati investor, hal ini terbukti dengan sampel yang diambil yaitu perusahaan yang masuk kedalam indeks LQ45 di Bursa Efek Indonesia dimana hanya perusahaan dengan kapitalisasi besar yang masuk dalam indeks tersebut.

Berikutnya political connections (POLCON) terbukti tidak berpengaruh signifikan terhadap pemilihan auditor berkualitas. Hipotesis yang diajukan tidak terdukung, sehingga dapat diketahui perusahaan yang memiliki political connections melalui kepemilikan oleh pemerintah tidak berpengaruh terhadap pemilihan auditor berkualias yaitu big 4 pada perusahaan yang masuk kedalam indeks LQ45 di Bursa Efek Indonesia. Hasil ini tidak sama dengan penelitian yang dilakukan (Guedhami et al., 2009) yang mengidenfikasi perusahaan publik yang memiliki political connections lebih memilih audior big 4 demi menunjukan bahwa orang dalam perusahaan ingin meningkatkan transparansi akuntansi untuk meyakinkan investor dari luar bahwa mereka menahan diri dari memanfaatkan koneksi untuk menguasai sumber daya perusahaan. Hal ini mungkin terjadi karena perusahaan yang telah terdaftar di Bursa Efek Indonesia dimana 
kepemilikannya adalah masyarakat umum mendapatkan tuntutan untuk menggunakan auditor berkualitas tanpa melihat adanya kepemilikan oleh pemerintah, hal ini juga dapat dilihat dari sampel yang menunjukan dari 15 perusahaan BUMN 10 diantaranya memilih auditor big 4.

\section{PENUTUP}

Berdasarkan hasil penelitian dapat disimpulkan bahwa $C E O$ yang memiliki power lebih kuat melalui kepemilikan saham di perusahaan yang dipimpinnya cendrung memilih auditor berkualitas perusahaan yang masuk kedalam indeks LQ45 di Bursa Efek Indonesia. Namun penelitian ini juga menemukan tidak ada hubungan antara political conections melalui kepemilikan saham oleh pemerintah terhadap pemilihan auditor berkualias oleh perusahaan yang masuk kedalam indeks LQ45 di Bursa Efek Indonesia.

Dalam penelitian ini tentunya masih memiliki keterbatasan diantaranya adalah penelitian ini hanya berfokus pada perusahaan yang masuk kedalam indeks LQ45 di Bursa Efek Indonesia dan hanya satu periode yaitu 2018. Selain itu penelitian ini hanya meneliti dua varibel independen yaitu CEO power dan political connection. Sebagai implikasi dari penelitin ini maka saran yang dapat diberikan oleh peneliti adalah 1). Penelitian selanjutnya disarankan menambahkan variabel kontrol yaitu ukuran perusahaan dan menggunkan proksi lain untuk political conections 2). Penelitian disarankan menggunakan sampel selama lima tahun.

\section{DAFTAR PUSTAKA}

Anugerah Endriawan Sudarno. (2015). Pengaruh tipe kepemilikan dan manajemen laba terhadap pemilihan kap dan penetapan fee audit pada perusahaan yang terdaftar di bei. Diponegoro Journal Of Accounting, 4(1), 1-8.

Arens, A. A., Elder, \& Beasley. (2015). Auditing dan Jasa Assurance. Pendekatan Terintegrasi (15th ed.). Erlangga.

Balsam, S., Krishnan, J., \& Yang, J. S. (2005). Auditor Industry Specialization and Earnings Quality. SSRN Electronic Journal, 1-46. https://doi.org/10.2139/ssrn.436260

DeAngelo, L. E. (1982). Mandated successful efforts and auditor choice. Journal of Accounting and Economics, 4(3), 171-203. https://doi.org/10.1016/01654101(82)90008-8

Faccio, M. (2006). Politically Connected Firms. American Economic Review, 96(1), 369386. https://doi.org/10.1257/000282806776157704

Finkelstein, S. (1992). Power in Top Management Teams. The Academy of Management Journal, 35(3), 505-538. https://doi.org/10.1057/9781137294678.0702

Guedhami, O., Pittman, J. A., \& Saffar, W. (2009). Auditor choice in privatized firms : Empirical evidence on the role of state and foreign owners. Journal of Accounting and Economics, 48(2-3), 151-171. https://doi.org/10.1016/j.jacceco.2009.08.003

Guedhami, O., Pittman, J. A., \& Saffar, W. (2014). Auditor choice in politically connected firms. Journal of Accounting Research, 52(1), 107-162. https://doi.org/10.1111/1475-679X.12032

Habib, A., Muhammadi, A. H., \& Jiang, H. (2017). Political connections, related party transactions, and auditor choice: Evidence from Indonesia. Journal of Contemporary Accounting and Economics, 13(1), 1-19. https://doi.org/10.1016/j.jcae.2017.01.004

Jensen, M. C., \& Meckling, W. H. (1976). Theory of the Firm: Managerial. Journal of Financial Economics, 3, 305-360. https://doi.org/http://dx.doi.org/10.1016/0304405X(76)90026-X

Kartikahadi, H., Sinaga, R. U., Syamsul, M., \& Siregar, S. V. (2012). Akuntansi Keuangan Berdasarkan SAK Berbasis IFRS. Salemba Empat.

Ouyang, B., Liu, Z., \& Sun, C. (2015). CEO Power and Auditor Choice. International Journal of Finance \& Banking Studies (2147-4486), 4(4), 44-51. https://doi.org/10.20525/ijfbs.v4i4.39
Auditor, CEO

Power and Political

Connection 
Auditor, CEO

Power and Political

Connection

190
Purba, J. H. V., Ratodi, M., Mulyana, M., Wahyoedi, S., Andriana, R., Shankar, K., \& Nguyen, P. T. (2019). Prediction Model in Medical Science and Health Care. International Journal of Engineering and Advanced Technology, 8, 815-818.

Palembangan, C., \& Dewi, C. N. (2017). Kekuasan CEO Dan Pemilihan Auditor. JURNAL RISET AKUNTANSI DAN KEUANGAN, 13(2).

Prayugi, G. (2015). Pengaruh Kepemilikan Perusahaan, Corporate Governance, Dan Earnings Management Terhadap Tipe Auditor Dan Audit Fees. Jurnal Akuntansi Indonesia, 4(2), 109-122.

Wiranata, Y. A., \& Nugrahanti, Y. W. (2013). Pengaruh Struktur Kepemilikan Terhadap Profitabilitas Perusahaan Manufaktur di Indonesia. Jurnal Akuntansi Dan Keuangan, 15(1), 15-26. https://doi.org/10.9744/jak.15.1.15-26 